\title{
PASTORAAT VIR DIE OUETEHUISE
}

\author{
DR. P. J. THEO KOEKEMOER
}

\section{INLEIDING.}

\section{1. 'n Pastorale noodroep.}

Hierdie artikel wil nie in die eerste plek akademies wees nie. Om dit egter lesenswaardig te maak, mag die akademiese voorveronderstellings in elk geval seker in geen enkele artikel in ' $n$ wetenskaplike blad ontbreek nie. Die gedagtes wat hier volg, is eerder uit die "nood" van die pastoraat gebore. Elke predikant wat 'n tehuis vir bejaardes binne sy gemeentelike grense het, ken daardie "nood" maar al te goed. Dis dieselfde gevoel wat daar in die hart van 'n Nederlandse predikant opgemerk word, wanneer hy, as "spesiale" predikant vir dei bejaardehuise, skryf: „Zal er nog van enige pastorale benadering van deze mens sprake kunnen zijn, deze een zeer gerichte aanpak vereist ... Kunnen wij nog wel iets voor hen zijn? Voor nieuwe indrukken staan zij nie langer open... dat verklaart ook vaak het gevoel van onmacht, dat zich daar ten aansien van so 'n patiënt van de pastor so licht meester maken. Hij ziet geen kans om nog tot een werkelijk gesprek te komen. Hy moet zich maar so snel mogelijk uit de voeten maken. Een schouderklopje, een paar vriendelijke woorden en hy is al weer op weg naar een volgend besoek..."'1) Ons as bedienaars van die Woord, as ons eerlik wil wees, het presies dieselfde gewaarwordinge en vrae. Juis dáár het ons baie vriendelike woorde en juis daar in dié tehuise lê vir ons die gevaar om met die „skouerklopje" te volstaan. Dit lyk vir ons of die predikante, wanneer hulle met die bejaardes te doen het, óók met die wat so gelukkig is om geen vorm van demensie te hê nie, die waarskuwing van hierdie Nederlandse kollega moet raaklees: „In géén geval zal de pastor zijn besoeken afkunnen met alleen een handdruk, zo in de zin van ,dag opa' of ,dag oma' en anders niets. Intuitief zal dan de bejaarde aanvoelen, dat hij ook door hem niet meer au sèrioux genomen wordt. Er zijn andere wegen, die wij kunnen gaan."

\section{2. „Spesiale Bemoeienis?"}

Toe die Algemene Kerkvergadering van 1973 gedink het om 'n begin te maak met so 'n ,zeer gerichte aanpak" deur te besluit, al was dit slegs in beginsel, om 'n predikant vir hierdie werk af te sonder, het dit nog drie jaar geduur voordat die beginselbesluit

1) Ds. A. de Groot. Artikel: „Pastorale zorg aan hen, die lijden aan ouderdomsdementie." in die bundel: „Pastorale Zorg aan Psychische Gestoordoen". Bookencentrum, s'Gravenhage, 1968, bls. 128. 
gerealiseer kon word. Die kerk het hierdie besluit geneem, nie omdat dit die kerk skielik bygeval het dat daar op 'n spesifieke arbeidsveld van die kerk besondere aandag geverg word nie, maar dit was en is vir die kerk nog altyd deel van sy groot en omvattende apostolaat. Wie die notule van die 1976 Algemene Kerkvergadering ter hand neem, sal opmerk dat onder die opskrif "Die Gemeentes", volg "Studentebearbeiding”, .Hospitaalbearbeiding”, „Gevangenisbearbeiding” en "Bejaardebearbeiding”, gevolg deur „Evangelisasiestandplaas" in die middestad van Johannesburg. Alhoewel die kerk nie graag praat van "spesialisasie" nie (.,spesiale predikante" is woorde met 'n eie gevoelswaarde; beslis nie gunstig nie), het die kerk tog, na ons beskeie persoonlike mening, verder gegaan op die pad van "spesialisasie", wat met die beroeping van studentepredikante en hospitaalpredikante begin is. Daar sal nou ook gevangenispredikante en predikante vir bejaardehuise beroep word. Waarom? Dit het uit die ervaring van die pastoraat baie duidelik geword dat, veral daar waar "groepe" lidmate hulle onder besondere omstandighede bevind, veral as die getalle dit regverdig, dit wel deeglik op die weg van die kerk lê om daardie besondere omstandighede in ag te neem. Studente, hospitaalpasiënte, gevangenes en bejaardes vorm vier groepe met hulle eie unieke behoeftes, behoeftes wat inderdaad van groep tot groep verskil. Elkeen van hierdie groepe verg ' $n$,zeer gerichte aanpak". Daarom is dit goed dat die kerk vir elkeen van hierdie groepe hulle „eie" predikant beroep. Dit gee aan die predikant die geelentheid om voltyds slégs aan hulle sy aandag te skenk; dit gee aan die predikant die geleentheid om op hierdie genoemde terreine te „,spesialiseer". Ons leef in 'n eeu waarin gespesialiseerde kennis geverg word. Dit is juis ook die behoefte aan só 'n gespesialiseerde kennis, wat die kerk nog 'n verdere tree laat gee het: die instelling van die "Pastorale Verwysingsdiens" vir mense met besonder gekompliseerde psigiese probleme. Is dit nie ook „spesialisasie" nie? Dit is wel opvallend dat die Algemene Kerkvergadering in verband met die beroep van 'n predikant vir bejaardes, besluit het dat hierdie beroep nie aan ander opdragte gekoppel moet word nie.

Sy ."gemeentelike bystand" in daardie gemeentes binne wie se grense die ouetehuise gelee is, is dus gekwalifiseerde bystand. Hy sal (met al die kragte tot sy beskikking) aan die kerkrade verantwoording verskuldig wees slegs vir sy arbeid in hierdie tehuise. Indien sy kragte ook deur ander arbeidsterreine van die kerk geverg sou word, sal die eintlike doel van die besluit noodwendig skade ly.

\section{Pastoraat.}

\subsection{Die Woord spreek pertinent oor die bejaarde:}

Ook hiér: Profetiese roeping as bedienaar van die Woord.

Hierdie man stap die bejaardehuise in. Hy is prédikant en slégs predikant wanneer hy daar instap. By die persoon waarheen hy gaan, 
vind ons ook van tyd tot tyd die medikus (en verpleegster) en sosiale werkster. Hy beklee nie een van laasgenoemde twee professies nie. Hy beklee 'n kerklike amp. Hy is slégs bedienaar van die Woord. Hy sal met die dokter en sosiale werkster van tyd tot tyd wel in sy pastorale werk oorleg pleeg; ja seker! Hy sal hulle egter nie kan vervang nie en moet hom ook nie laat druk of aanmoedig, of selfs laat verlei om een van hierdie laasgenoemde professionele mense se werk te doen nie. Hy het immers gehoor, tydens sy bevestiging, dat die kerk vir hom gesê het: „Want net soos die werk van ' $n$ herder is om aan die kudde wat aan hom toevertrou is, weiding te verskaf, dit te lei, te beskerm en te regeer, so is dit ook met hierdie geestelike herders wat aangestel is oor die gemeente wat God tot die saligheid roep en as skape van sy weiding beskou. Die weiding waarmee hierdie skape versorg moet word, is niks anders nie as die verkondiging van die goddelike Woord met die daarby behorende bediening van die gebede en die heilige sakramente. Dieselfde Woord van God is ook die staf waarmee hierdie kudde gelei en geregeer word." (Formulier om die dienaars van die Woord te bevestig.)

Uit die ontsaglike rykdom van wat die Woord van God te sê het aan die adres van hierdie bepaalde mense, in hierdie bepaalde situasie, kan die prediker lustig gaan delf. ${ }^{2}$ ) Voor hom, in die sitkamer, (sy „kerkgebou") sien hy hulle van wie die Woord melding maak, diegene van wie Jesaja sê: „en tot die ouderdom toe is Ék dieselfde, ja, tot die grysheid toe sal Ek julle dra; Ek het dit gedoen, en Ek sal julle opneem en het dit gedoen, en Ek sal julle opneem, en Ek sal dra en red." (46:4.) Dis hulle wat genoem word die "hoogbejaardes" (Gen. 24:1; 1 Kon. 1:1; Jos. 13:1; 23:1, 2), diegene wat lewenssat en versadig van lewe is (Gen. 35:29; Job 42:17; 1 Kron. 23:1, 2), van wie Elifas die Temaniet praat: „Ook is daar grys hare, ook bejaardes onder ons ..." Job 15:10.

En wanneer die predikant in sy profetiese roeping, as bedienaar van die Woord, die weiding aan hiérdie skape bied, sal hy terdeë onthou dat, wanneer die dae waarvan die mens sê dat hy daarin geen behae het nie, aangebreek het, (Pred. 12) hy die weiding beslis nie meer kan aanbied as „vaste spyse" nie, maar eerder as "melk" (1 Kor. 3:2). Aan húlle sal hy die evangelie van die „wederopstanding van die vlees en 'n ewige lewe"' verkondig, 'n woord wat hulle met blýdskap sal aanvaar.

Hierdie beter, hoopvoller klank vir die bejaarde, hoor ons uit die mond van Moses: „Vir die gryshare moet jy opstaan, en die persoon van 'n grysaard eer; en jy moet jou God vrees. Ek is die Here." (Lev. 19:32.) Die nakoming van hierdie vereiste verbind Moses hier duidelik met die godsdiens, met die vrese van die Here.

2) Dr. C. Gihuis. „Pastorale Zorg aan Bejaarden“. Kok, Kampen 1956, bls. 97 tot 166. 
Letterlik staan hier eintlik geskrywe: ,jy moet die aangesig van die grysaard versier", in teenstelling met ontsiering.

Die profeet Jesaja het eeue na Moses hierdie eerbied vir die bejaarde in die profetiese aankondiging oor die trotse val van Babel betrek: „Ek was toornig op my volk. Ek het my erfdeel ontheilig en hulle in jou hand oorgegee: jy het hulle geen barmhartigheid bewys nie, op die grysaards het hy jou juk baie swaar laat druk..." (Jes. 47:6.)

Hierdie verering van die oues van dae, wat in Israel op grond van die Woord onderhou is, vind ons ook by ander oud-oosterse volke van daardie dae. Die Griekse „presbeuo" dui die oudste aan maar ook diegene wat geëer word, wat voorrang geniet, wat regeer en as gesante optree. By hierdie volke is dit egter bloot ' $n$ deel van hulle kultuurpatroon. In Israel word in die ouderdom iets van die goedheid van God gesien. Ons eer eintlik God in sy genadegawe wanneer ons vir die bejaarde opstaan. Die groot waardering vir die ouderdom blyk ook daaruit dat "die oudstes" belangrike posisies beklee. Reeds Abraham het die kneg wat "die oudste" in sy huis is, in bestuursfunksie geplaas. Hierdie kneg het die eer tebeurt geval om 'n vrou vir sy seun Isak te gaan soek. Moses moes uit die volk sewentig "oudstes" as mederegeerders aanstel (Num. 11:16). .Wee daardie land wie se koning 'n kind is..." (Pred. 10:16). Vergelyk verder die heilsaankondiging van die profeet Sagaria (8:4) in die belofte van heerlike seëninge: - "So sê die Here van die leërskare: daar sal weer ou manne en ou vroue op die pleine van Jerusalem sit - elkeen met sy stok in die hand vanweë die veelheid van hulle dae." Een van die seëninge uit die Messiaanse heilstyd, sal volgens Jesaja (65:20) wees dat in Jerusalem nie meer suigelinge sal wees wat net 'n paar dae oud geword het nie, of grysaards wat hulle dae nie voluit lewe nie.

Die oudag word as 'n besondere seën beskou omdat dit die dag is van die lewenswysheid en diepere insig in sake, op grond van die lang lewenservaring. Wanneer die jong koning Rehabeam die raad van die oudstes van die volk in die wind slaan, en in plaas daarvan die raad van die jongmanne volg om sy volk steeds harder te dryf, maak hy ' $n$ groot fout. (1 Kon. 12:6.) Die Spreukeboek is 'n les van die ouer leermeester aan die jonger seun wat nog wys moet word (Spr. 2:2.) Die spreukwoorde kom gewoonlik van die oudstes (1 Sam. 24:14). Die oorheersende gedagte is dat die rypere leeftyd ook wysheid teweeg bring en daarom eerbiedig moet word. Ook in die Nuwe Testament staan sake nie anders nie. Die leier van die gemeente word die „presbuteros' of „,presbutes" genoem waarvan ons die eerste keer in Handelinge 11:30 hoor. Dat ons hier aan ampsdraers, die ouderling moet dink, is wel seker, maar dat hulle juis "oudstes" genoem word, sal seker ook beteken dat hulle uit die oúdstes van die volk gekom het om hierdie opsigwerk te doen. 
Ook Paulus vra dat eerbied teenoor die ouer mense betoon moet word. Die Nuwe Testament staan op die basis van die Ou Testament; dis daarom ook begryplik dat Paulus vir sy jong vriend Timotheus skryf: „, n Bejaarde man moet jy nie hard bestraf nie, maar vermaan hom soos ' $n$ vader, jongeres soos broers, bejaarde vroue soos moeders..." (1 Tim. 5:2.) Dit beteken dat ons daardie oumense wat in sonde lewe op 'n eerbiedige wyse moet reghelp in ons pastorale gesprek na Christus moet lei. Paulus vra die kinders en kleinkinders dat hulle sal leer om teenoor hulle eie huis eerbied te betoon en vergelding te doen aan hulle ouers, omdat dit goed is en aangenaam voor God (1 Tim. 5:4). Net soos in die Ou Testament, is die eerbied vir die ouer geslag gegrond in God se wil, naamlik dat dit goed is en aangenaam voor God. En wanneer Paulus vra dat die weduwees wat waarlik weduwees is, geëer moet word, bedoel hy waarskynlik die wat na die dood van hulle man eensaam agtergebly het, meestal van alle steun en hulp beroof. Teenoor hulle in die besonder, het die kerk ook 'n diakonale opdrag om uit te voer, tot in die materiële sin van die woord. Ook die apostel Petrus (1 Pet. 5:5) gee opdrag aan die jongeres om aan die oueres onderdanig te wees en vra om met "ootmoed bekleed" te wees. Dit wil sê, die ootmoed moet ..omgebind" (beklee) word, soos 'n vrou wat bedien, haar voorskoot ombind. Die apostel Petrus kon inderdaad hier gedink het aan daardie les wat sy Heer hom geleer het met die voetwassing van die dissipels. Soos die Heer Homself soos ' $n$ dienskneg geklee het, 'n skottel geneem het en die werk van 'n dienskneg gedoen het, so moet ons ook ten opsigte van veral die oueres optree. Die uitdrukking "met ootmoed beklee te word" is in een van die Nederlandse Bybelvertalings deur professor Brouwer pragtig soos volg weergegee: „En gij allen, kleedt $u$ in het onderling verkeer met deemoed." In ons onderlinge verkeer, ons omgang met alle mense, maar in besonder word die bejaardes hier genoem, moet die nederigheid nie ontbreek nie.

Ook dien daarop gewys te word dat Jesus self in sy gesprekke met die Skrifgeleerdes en die Fariseërs vir die oumense in die bresse getree het. Jesus sê: (Mat. 15:4 tot 6) „Eer jou vader en jou moeder; en $\mathrm{Hy}$ wat vader en moeder vloek moet sekerlik sterwe. Maar julle sê elkeen wat aan vader of moeder sê: enige voordeel wat $u$ van my sou kan geniet, is 'n offergawe - die hoef sy vader of sy moeder gladnie te eer nie. So het julle dan die gebod van God kragteloos gemaak ter wille van die oorlewering." Die saak staan hier so dat die Skrifgeleerdes en Fariseërs se verklaring van die vyfde gebod (,eer jou vader en jou moeder...") volgens hulle eie oorlewering dit moontlik maak vir 'n kind om aan sy ouers te sê dat hy aan hulle geen onderhoud kan gee nie, omdat hy die bedrag van die onderhoud as ' $n$ offergawe vir die tempel bestem het. Daarom noem Jesus hulle, ,geveinsdes", omdat hulle onder die dekmantel 
van godsdiens hulle verantwoordelikheid teenoor hulle ouers, wat nou nie meer vir hulleself kan werk nie, ontduik. Jesus gebruik 'n woord van Jesaja om hulle tot nadenke te stem: „Hierdie volk nader My met hulle mond en eer My met die lippe, maar hulle hart is ver van My." (Matt. 15:8.)

Die bejaarde wat diep bewus daarvan is dat hy/sy daagliks in die skaduwee van die dood leef, dat die tyd om „,huis toe" te gaan op een of ander tyd moet aanbreek, kan in gedagte neem dat vir hulle wat leef in die doodskaduwee, hét daar 'n lig opgegaan: „Die volk wat in duisternis wandel, het 'n groot Lig gesien, en die wat sit in die land en skaduwee van die dood, vir hulle het 'n lig opgegaan." (Matt. 4:16.)

Laat daar hoegenaamd geen twyfel wees oor één saak nie: die predikant van die ouetehuise sal die voorreg hê wat baie ander predikante nie het nie: hy sal naamlik (in oorleg met die kerkrade natuurlik, met name veral die ouderlinge) 'n erediens vir weeksdae kan bepaal - en daarby van 'n gehoor seker wees. Hy sal nooit "vir banke" preek nie - daarvoor is sy skape te honger. En as hy klaar gepreek heet, sal die kerkgangers hulle dankbaarheid bewys deur 'n handdruk te kom gee, mits hulle „uitgevind" het dat hy graag sy hand na húlle uitsteek! En met hierdie "hand uitsteek" het ons midde in 'n voortvloeiende deel van die prediking, die pastorale gesprek geland. Omdat die prediking hulle verlede, hede én toekoms sinvol maak, sal hulle uitsien na die "volgende keer" én uitsien na sy pastorale besoek. (Want sosiale besoekies, hoe goed en gaaf dit ookal mag wees - daarvoor sal hy nie tyd hê nie.)

\subsection{Die pastorale besoeke en gesprekke. (Verdere voort- gaande sielsorg.)}

Emosie is iets wat baie gou, feitlik onmiddellik, oorgedra word. Ons weet dit: jý is kwaad en maak dan ook ánder kwaad! Laat 'n predikant sy humeur in 'n kerkraadsvergadering verloor, en kyk wat gebeur! Alle emosies wek emosies. Is mens gespanne dan maak jy ander met wie jy praat, ook gespanne. Dis 'n stukkie mensekennis wat hier (en orals) toegepas moet word. Die pastor moet sy besoeke rústig en kálm by hierdie mense aflê. Hy moet onthou dat hy die bejaardes in spanning bring sodra hy begin "loer" na sy horlosie. Hy moet bereid wees om nie slegs te hoor nie maar veral moet hy kan lúister. Hy kan en moet aan die gesprek leiding gee, want hy sal weldra, om met die bediening van die Woord in gesprekvorm voort te gaan, van die platvorm van wind en weer, van koeitjies en kalfies moet afklim. Hy moet by die punt kom waar die sielsorg, wat reeds aanvang geneem het in die prediking, nou verder gevoer kan word op die persoonlike vlak. Hy moet in hierdie gesprek met die toepassing van die Woord verder gaan. Sielsorg is in sy kern en wese óók Woordverkondiging, 'n legitieme gestalte daarvan. 
Eduard Thurneysen wys op die gevaar wat in 'n piëtistiese vorm van sielsorg opgesluit lê, naamlik, dat die enigste voedsel wat waarlik voed, naamlik die Woord, hier plek maak vir die subjektiwiteit van die mens. Hy vergelyk hierdie gevaar met 'n klip waarteen die Bybelse sielsorg kan stamp... en sink! Die sielsorg in die kamers van die ouetehuise moet "Ausrichtung des Wortes Gottes" aan die enkelinge wees. Soos alle kerklike diens, is ook hierdie diens in die Woord gefundeer. Dit is hierdie Woord wat om ,in mancherlei Gestalt ausgerichtet zu werden" vra. ${ }^{4}$ ) Dit kan nooit verruil word vir dierbare geselsies en 'n vriendelike klop op die skouer, waarna die pastor so gou as moontlik na die volgende kamer gaan nie. Indien die voedende, versorgende, opwekkende, lewende Woord, in sy alles omvattende geldigheid, in hierdie sielsorggesprek op die agtergrond raak, waarmee moet die skape dan in hulle worsteling op die pad waarop "die sterk manne krom word" en die "malers die werk staak..." gevoed word? Vir die sielsorger is die mens daar voor hom, die deur God aangesprokene. Dít maak die sielsorg eers sinvol. Die sielsorger sien die mens-in-nood in sy sondaarskap. Hy sien hom egter altyd as ' $n$ sondaar op die pad van vergifnis. Daarom kan hy praat van sonde, genade, bekering, geloof ens. 'n Sielsorger wat slegs gerig en oordeel oor die sonde aankondig, terwyl genade en vergifnis weggelaat word, is geen sielsorger nie. Sielsorg kry op hierdie punt 'n sterk pastoraal-diakonale aksent. Die sielsorger verkondig en verklaar aan daardie mens in sy nood dat God wil help. Sielsorg word op hierdie punt priesterlike diens. Die mens in nood is eintlik ' $n$ hulpbehoewende mens. In Christus is God die barmhartige Vader. Profeties-priesterlik gaan die pastor in sy sielsorgwerk voort. Hy is net ' $n$.,stem" wat uitroep. Die pad van die Here moet reguit gemaak word. Hy is nie die lig nie maar moet van die lig getuig. Hy wys heen en sê: "Daar is die lam van God wat die sonde van die wêreld wegneem." Anders as die medikus het die sielsorger met die hele mens te maak, maar met die aksent op die pneumatiese. Hy sal met die mens in hierdie laaste en diepste dimense te doen kry: sy verhouding tot God. Dieselfde heil wat van die kansel af aan die gemeente verkondig word, sal hy ook hier uitsê. Sy gesprek bly enduit onder die gesigspunt van die verkondiging van die evangelie, geadresseer aan die hele mens, in die geheel van sy nood. Belangrik vir die pastor is dat hy deurgaans sal onthou dat die woord wat hy spreek nie sy eie woord is nie. Daarom juis is hy 'n dubbele luisteraar omdat hy moet sê: "so sê die Here." Hy moet goed luister na wat God in Jesus Christus spreek én hy moet luister na die stem van die skape. Dit is die Woord van

3) Dr. G. Brillenburg-Wurth. „Christelyke Zielsorg in het Licht der Moderne Psychologie." Kok, Kampen 1955, bls. 101 en 102.

42 Eduard Thumeysen. „Die Lehre von der Seelsorge.” 2 Auflage. Evange.riskische Verlag, Zollikon - Zürich - 1957. 
die "Gans Andere“ wat die gesprek lei en begelei. Die „kerugma” gaan in die gesprek in. Vertikale en horisontale lyne ontmoet mekaar in hierdie gesprek. ${ }^{5}$ )

Wanneer die sielsorger deurdring is met sy profeties-priesterlike roeping, sal hy nie op die seepgladde pad om mense na sy persoon „te trek" val nie, maar sal hy mense na Jesus toe lei. Dan bring hy nie mense na die sielsorger toe nie maar mense na Jesus Christus toe.

\section{Hierdie pastoraat het egter besondere probleme:}

\section{1. "Wie niet studeerd is niet bekcerd" (Gerontologie.)}

Die 1976 Algemene Kerkvergadering het met die verslag van 'n studiekomitee van die kerk insake die instelling van 'n „Pastorale Verwysingsdiens" saamgestem. In hierdie verslag lees ons soos volg: "Dit is moontlik dat die pastor in sy doel om die Woord na die mens te bring, nie kan slaag nie indien daar by hom nie voldoende kennis is van die psigiese gesteldheid van daardie mense met wie hy te doen het in sy pastorale gesprek nie. Hierdie psigiese gesteldheid kan soms gekompliseerd wees. Dit sal vir die pastor uiters waardevol wees indien hy beskik oor kennis aangaande kognisie, emosies, motivering, strewings en verwagtings, aanleg, omgewingsbeïnvloeding, konflikte, frustrasies, verdedigingsmeganismes, obsessies, kompulsies en geesteskrankhede in verskillende vorme. Ter wille van 'n mensgerigte pastoraat, maar dan 'n pastoraat soos die Woord van God dit vereis, behoort die pastor kennis te dra van hierdie psigiese gesteldhede." (Sien Notule bls. 65.)

Wat ons in die voorafgaande gesê het oor die bediening van die Woord asook oor die pastorale besoeke en gesprekke, dit wat in die "gewone" gemeente so vanselfsprekend geld, geld net so vanselfsprekend hier ook ... maar, hier sal baie meer as in die deursnee gemeente, "blokkerings" in die pad van die verkondiging lê, hindernisse, stoornisse wat die taak van die pastor uitermate problematiseer. Daarmce bedoel ons nie dat kerklike sorg vir die bejaarde (pastorale sorg, diakonale sorg, ensovoorts) dan radikaal en kwalitatief met kerklike sorg vir die ander mense moet verskil nie - dié wat nie bejaard is nie. Waarom sou hierdie sorg dan heel anders moet wees as sorg vir die ander? Woordverkondiging bly Woordverkondiging aan wie se adres dit ookal gerig is. Barmhartigheid bly barmhartigheid, aan wie dit ookal bewys word. Ons kan egter nie verstaan dat enkelinge senuweeagtig begin word sodra

5) Dr. E. L. Smelik. Het Gesprek in de Pastorale Theologie, bls. 15 en 16 in die rapport: „Over de Onderlinge verhouding van Psychoterapie en Zielsorg. Rapport van Psychoterapie en Zielsorg. Rapport van die Raad van Beheer oor die stigting vir Geestelike Volksgesondheid. Boekencentrum, N.V. s'Gravenhage, 1956. 
daar in die kerk erns gemaak word om die mens met wie die kerk werk, die mens aan wie die evangelie verkondig word, beter te ken nie! Hierdie kennis van die mens kan tog sekerlik alleen tot groot voordeel strek vir hulle wat vanuit die kerk in Christus Naam na die mens toe gaan. Vanuit die kerk werk ons in elk geval nie met tegnieke van verskillende soorte terapieë waarmee psigoterapeute na die mens toe gaan nie." Die enigste "tegniek" wat die persoon (pastor, ouderling, diaken, gemeentelid) vanuit die kerk hanteer, is die gesprek met die mens daar voor hom of haar, en let wel, 'n gesprek wat in die omgewing van die Woord moet plaasvind, in daad van barmhartigheid wat vanweë die groot Barmhartige, Jesus Christus verrig moet word. Maar... watter ontsettende flaters kan hierdie "weldoener" nie maak nie, as hy/sy met die liggaamlike en geestesgesteldheid van daardie mens na wie toe hy gaan nie rekening hou nie. Byvoorbeeld: sou mens 'n vrou in haar moeilike oorgangsjare vanweë haar invalusie melankolie, nie beter verstaan wanneer sy in hierdie tyd so dikwels geen oog het vir die volle lewe wat nog op haar wag nie? Sou mens haar op ouderdom 45-55 nie anders in hierdie gesprek benader as die jare 30-35 nie? Sou mens nie die gevoelens van depressie, lusteloosheid, gejaagdheid, troosteloosheid, minderwaardigheid, ingesonkenheid en geestelike verwarring onein dig beter verstaan as jy kennis geneem het van die lewensstadium van die oorgangsjare wat veral by sommige vroue so akuut kan wees nie? Sou, byvoorbeeld, 'n persoon wat namens die kerk met die jeug te doen het, die weerbarstigheid van ' $n$ jong tiener in die puberteit nie veel beter begryp as hy/sy kennis dra van hierdie stukkie moeilike pad in die lewe van ' $n$ kind nie? Het mens nie hierdie kennis nie, kan die optrede in woord en daad radikaal verkeerd wees vanweë 'n onbegrip, vanweë „gebrek aan kennis". Derhalwe: iemand wat 'n ,,klaagkous" geword het in die sewentiger jare, moenie byvoorbaat as 'n "lastige" oumens uit die pad gestoot word nie. Daar is verskille tussen ' $n$ bejaarde en 'n bejaarde, en daar is sommer goeie en grondige redes vir hierdie individuele verskille. Hierdie gesprekke van diegene wat vanuit die kerk in Christus Naam na die mens toe gaan, by geval die oú mens, is nie gesprekke soos die "sessies" in die spreekkamer van die sielkundige nie. Daar is ooreenkomste maar daar is ook belangrike verskille. Die deel van die sielkunde wat met die ontwikkelingsstadiums van die mens te doen het, het as ondervertakking die gerontologie, wat uitsluitlik met die bejaardes besig is en ook ' $n$ mediese sektor, die geriatrie wat belangrike kennis na vore gebring het. Vir hulle wat met gespesialiseerde werk in veral oue tehuise besig is medici, predikante, sosiale werksters, verpleegsters, matrones - is hierdie kennis van die mens met wie hulle werk, van groot waarde.

Die pastor in die ouetehuise sal byvoorbeeld, meer as gemiddeld kennis moet dra van onder andere die volgende: 


\subsection{Psigiese Involusie.}

Die mens in sy eenheid as liggaam en psige, het op sy oudag te doen het met psigiese involusie, 'n soort van terugwaartse beweging van die menslike gees, terug na die van ' $n$ kind. ' $n \mathrm{Be}$ jaarde kan weer "kinds" word indien hierdie teruggaan radikaal geskied. Laat ons egter dadelik stel: bejaardes verskil van persoon tot persoon. By die een is dit nouliks merkbaar, by die ander staan dit opsigtelik op die voorgrond. Sommige bejaardes is grootliks hiervoor gespaar. Ons dink aan groot staatsmanne en ander wat op ver gevorderde leeftyd die leisels nog styf in die hand kon hou. Daar is dus ook uitsonderings. Elkeen sal seker graag onder die uitsonderings wou val; ons ken 'n hele paar bejaardes wat nie wil weet dat hulle oud is nie en juis daarom in opstand teen hulle "kwale" is, met die gevolg dat hulle nie kan aanpas by die omstandighede van die oudag nie, en hulleself bitter ongelukkig maak. So 'n persoon is gewoonlik aggressief, bakleierig en voortdurend in spanning. Deur sy wanaanpassing aan sy ouderdomstyd is hy die hoofoorsaak van sy eie ongelukkigheid en maak so 'n persoon ook ander mense met wie hy of sy saamleef, kronies ongelukkig!

Agteruitgang van psigiese funksies kan o.a. ten opsigte van die volgende gesien word:

Die verlede en hede: die waarnemingsfunksie kom in gedrang. Hulle het ' $n$ besondere tydsin en sê van tyd tot tyd: "hoe vinnig gaan die tyd nie verby nie?" Hierdie „klok" loop in die hoë ouderdom vinniger as in die jeugjare. Gewaarwording en waarnemingsvermoë is gewoonlik nie meer so skerp nie. Deur die ouerwordende sintuie is die waarneming minder intens. Ook word die gesigsveld kleiner. (Daarom is dit gevaarlik vir ' $n$ bejaarde om agter die stuurmeganisme van ' $n$ voertuig in te klim - ook die reaksievermoë is baie stadiger. Voordat die remme getrap word, het die ongeluk reeds plaasgevind.) Hy „beleef" minder gebeurtenisse as in dae van weleer, raak ook minder geïnteresseerd in baie sake. Nuwe name en nuwe gesigte word makliker vergeet. Mens sou verwag dat in 'n lewe waarin belewenisse en afwisselende boeiende momente minder in getal en in intensiteit voorkom, verveling moet intree. Feit is ook dat die "Wêreld" rondom die bejaardes steeds kleiner word en hy daarom op homself/haarself aangewese is en die eie ego maklik in die sentrum te staan kan kom, soos in die kinderdae. Nuwe dinge word nie maklik opgeneem en verwerk nie; dit vermoei hulle eerder. Ons vind by die bejaarde hierdie merkwaardige en belangrike kenmerk in hulle kenwêreld: hullo gaan leef in die herinnering (retrospeksie). In die dae van weleer was hulle prospektief, het vooruit beplan; dit was die dae van die verwagting. Nou leef hulle in herinnering. Die vraag kan gestel word wat tog die oorsake van so ' $n$,.teruglewe" kan wees? 'n Antwoord kan moontlik daarin gesoek word dat deur 
verswakking van psigiese spankrag en opmerksaamheid, die nuwe en aktuele van die dag nie meer sterk opgeneem kan word nie. Omdat hierdie funksies in sterk mate (biologies) liggaamlik veranker is, is dit begryplik om hierdie verskynsel medies terug te voer na veranderinge wat daar moontlik in die brein plaasvind; aldus die dokter. Maar daar is ook ' $n$ ander faktor wat onthou moet word. Opmerksaamheid en waarneming staan sterk onder invloed van die "ek-betrokkenheid", dit wil sê sodra iets gebeur wat myself raak, waarby ek betrokke is, is die opmerksaamheid lewendig. Die dinge wat die bejaarde self en sy familie raak, interesseer hom steeds die ander minder. Verder moet ons onthou dat hoogbejaarde mense in die daaglikse maalstroom van die lewe meestal eenkant, opsy geplaas is. Hulle staan langs die "kantlyn" en kyk en is naderhand gewoond om self nie "saam te speel" nie. By menigeen is dit ingeprent dat hy/sy tog nie "daarby hoort" nie, en daarom is dit maar aie beste om opsy te staan, want ,hulle hou tog nie met my rekening nie!" Hierdie belewing kan ook in die afname van die belangstellings en tanende interesse van die meeste bejaardes ' $n$ rol speel.

By hierdie psigiese faktor van die "teruglewe" (retrospeksie) sluit ' $n$ naasliggende faktor aan. Die rol wat die bejaarde in die samelewing speel, is oneindig geringer as die waaraan hy vroeër jare gewoon was. Toe was hy nog baas van sy plaas en heer van sy hoewe. Dit geld man en vrou. Nou staan hulle daar, soms so verskrompeld en vereensaam, miskien aan ' $n$ stoel gebonde, starend deur die venster na buite, dalk in ' $n$ agterplasie (van steenkool en vullisblikke). Hoe maklik $k a n$ in hierdie gedagteklimaat nie 'n ontsetten de minderwaardigheidsgevoel van .,ek is tog niks meer werd vir iemand nie", ontwikkel? Daar word na vergoeding, kompensasie van die eens so volle en belangrike lewe gesoek; jy gaan dus maar teruglewe in daardie goeie ou dae ten einde jou uit jou huidige „ballingskap" van 'n ouetehuis uit te ruk. In die verlede was jy van belang, jy was ,iets", maar nou is jy ",niets". Die herinneringe word steeds mooier, en "vandag se dae" en „vandag se mense" steeds leliker. Geen wonder dat dit deur die bejaardes so oordryf word dat hulle in "die paradys" van weleer terugleef! (Die sielkundige Adler, praat van 'n "oorkompensasie" by die bejaardes.) Só word die selfgevoel, die gevoel van belangrikheid en eie waarde, die goeie gevoel van selfrespek, ten alle koste gehandhaaf. (.,Vroeër dae was alles nog so goed, maar vandag...?" Met hierdie verskynsel kom ons ook by een van die oorsake van die .generasiegaping" tussen die ou geslag en die jong geslag.)

Herinneringsbeelde van die jongste verlede is skaars. Dit is uit die verswakte opmerksaamheid te verklaar - behalwe ten opsigte van daardie gebeurtenisse in die jongste tyd waarin die bejaarde self (of sy kinders) betrokke is. 
Derhalwe: enigiemand wat ' $n$ bejaarde gaan opsoek, in ware profeties-priesterlike bewoënheid en ontferming, om in meestal vereensaamde mensekind in die staat van afsondering ' $n$ hand van broederskap in die geloof te reik, moet tyd en geduld hê. Tyd om te luister na hierdie dae toe hulle nog in die „paradys" gelewe het, geduld om hulle nie af te kam, te vermy en uit te stoot omdat "vandag se geslag" so onhebbelik in hulle oë is nie. Voel hulle verlate? Hulle kan daarop gewys word dat Christus aan die kruis van God verlate was en dat juis $\mathrm{Hy}$ ons van-God-verlatenheid daarmee opgehef het.

\subsection{Ons benadering van die bejaarde. (Optrede en gesprek.)}

Wie na die bejaardes op besoek gaan, in ons geval kerklikpastorale besoek, sal voordat daar eén woord met hulle gepraat word, onthou dat dit vanselfsprekend is dat die besoeker se optrede sal spreek van belangste!ling, eerbied, verdraagsaamheid, beskeidenheid, vriendelikheid, vertroue, waardering, taktvolheid, en noem maar op. Heel belangrik is dus die besoeker se manier van benadering. Daar is mense wat met bejaardes omgaan asof hulle kinders is. Hulle word be-oupatjie en be-oumatjie vandat hulle daar kom totdat hulle vertrek. Die bejaarde kan nie anders nie as om behoorlik aan te voel dat hulle oumensies is nie, al word dit hoe goed bedoel. Soms word hulle nog letterlik gestreel presies soos mens met 'n babatjie doen. Nee, ons moet ons bejaardes juis nie so "terugvoer" na hulle kinderdae nie, al is hulle ook so "kinds" dat hulle gedrag as "kinds" bestempel kan word. Hulle moet juis nie deur ons besoek agtertoe nie maar vorentoe gebeur word, weg van die greep van hulle .goeie ou dae", met hulle voete geplaas in die hede en met 'n uitsig, 'n vergesig op 'n groot toekoms wat op hulle wag. In 'n sekere ouetehuis waar ons van tyd tot tyd saam met hulle gaan eet, ' $n$ tehuis waarvoor ons die allergrootste waardering het, word diegene wat nog in die eetkamer aan tafel kan kom, verdeel in twee groepe: die "hasies" en die „skilpadjies". Al te soetlik! Die eerste etensklok lui vir die stadige ou "skilpadjies" om vanaf die kamers na die eetsaal in beweging te kom. Die tweede klok lui sodra die "skilpadjies" hulle plek ingeneem het aan tafel; dan kom die vinnige "hasies" nader!

Ons wil daarvoor pleit dat diegene wat hierdie bejaardes na liggaam en siel versorg, asook hulle besoekers, te alle tye ongekunsteld en natuurlik teenoor hulle sal optree as volwaardige volwassenes, en benaminge sal gebruik wat hulle nie nog meer in die stroom van regressie (teruggang) waarin hulle verkeer, sal laat beland nie. Toe hulle vyftig-sestig jaar was, het almal hulle „oom" en „tante” of "tannie" genoem. Dis 'n tipies Suid-Afrikaanse prerogatief om so aangespreek te word. In Nederland is slegs jou 
bloedfamilie „oom" en „tante“. Hierdie naam „oom Jan“ en „tant Bettie", laat ons bejaardes voel dat hulle nog die "grootmense" van weleer is, laat hulle nie soos kinders voel nie.

Ons gaan dus op grond van profetiese roeping, uit belangstelling na hulle toe, nie slegs uit blote pligsbesef nie. Gaan mens slegs uit blote plig, sal hulle jou tog gou „uitvind” omdat hulle aanvoeling skerper as wat mens dink kan wees. As jongere gaan jy ook in eerbied en respek. Dit is die begin van 'n suksesvolle besoek. Buitendien, jy as kerklike besoeker gaan omdat jy daarheen gestuur is. Jy het 'n Sender agter jou. Dan kom hulle menswees in die lig van Jesus Christus te staan. Hy is ware God en ware mens wat met ons swakhede medelye het. In die lig van sy evangelie is die menswees nie slegs op sigself aangewese nie; menswees beteken ook om met - 'n ander - mens te wees, „delend in mekaar se vreugde, delend in mekaar se smart." Die gesprek is die kontakmedium, die ontmoetingsmiddel in hierdie met - die - ander wees. In die Bybel is dit so dat God weer met die gevalle mens deur middel van gesprek kontak maak. (Gen. 3:9 en 10), met Hagar by ' $\mathrm{n}$ fontein in die woestyn (Gen. 16), met Abram (Gen. 17), met Moses (Eks. 33:11). Ons dink aan gesprekke tussen Jesus en Nikodemus (Joh. 3), met die Samaritaanse vrou (Joh. 4), met Petrus (Joh. 21). Paulus het behalwe die prediking, van die gesprek met die mense gebruik gemaak. Ons dink veral aan sy werk in Efese, waarvan ons lees: „En hy het in die sinagoge ingegaan en vrymoediglik drie maande lank met hulle geredeneer en hulle probeer oortuig van die dinge wat die koninkryk van God aangaan. Maar toe sommige hulle verhard en ongehoorsaam was en voor die menigte aanhou kwaadspreek van die Weg, het hy van hulle weggegaan en die dissipels afsonderlik geneem en elke dag in die skool van 'n sekere Tiránnus samesprekings gehou. En dit het weer twee jaar lank geduur, sodat al die inwoners van Asië die woord van die Here Jesus gehoor het, Jode sowel as Grieke."

Wat is tog eintlik die gesprek? lemand het dit goed gestel toe hy gesê het: die gesprek is ' $n$,,geestelike ontmoeting op die basis van saamwees op die gemeenskaplike vlak van die gewone lewe, 'n ontmoeting waarby die persoonlikheid van albei wat in die gesprek betrokke is, altyd gehandhaaf en respekteer sal word, ook al is die ander een nog soveel anders." Dit geld ook die gesprek tussen bejaarde en kerklike besoeker, maar... die basis van die gewone lewe word altyd betrek in die lig van die Woord van God, ja onder direkte heerskappy van hierdie Woord. Beide staan saam in hierdie wêreld, wat God se wêreld is. Ons sê weer: die outoriteit wat in hierdie gesprek na vore moet kom, is die outoriteit van die Sender.

Die kerklike ampsdraer plús daardie gemeentelid wat kragtens die priesterskap van elke gelowige na hierdie mens in sy/haar besondere situasie gaan, moet behalwe die eie nederigheid en 
respek vir die ander, een ding goed kan doen, naamlik luister. Kan die besoeker hierdie „een ding” aanvanklik nie so goed doen nie, moet hy dit maar aanleer. Die ampsdraer, in besonder die predikant en ouderling, moet as't ware na twee kante toe luister.

Daar moet goed geluister word na alles wat in woorde en houdinge uit die hart en mond van die ander voortvloei. Op die probleem van die ander sal in die lig van die Woord van God ingegaan moet word. Dít sal die Woord van vergifnis, redding, waarskuwing, vernuwing en hoop wees. Die mens daar voor jou is ' $n$ mens wat gebring moet word vanaf sy konkrete lewenssituasie waarop en waarin hy hom mag bevind, na God wat in Christus Jesus hom/haar te hulp wil kom.

\section{Slotopmerking. 'n Tikkie humor.}

Ons tree dus as reformatoriese kerke ons bejaardes uit pastorale en priesterlike bewoënheid tegemoet. Ons doen dit met die geopende Bybel. Daar waar bejaardehuise is, daar moet die Woord van God aan hulle verkondig word. Nee, sulke luukse ouetehuise wat 'n eie kerkie het, ken ons nog nie. Die sitkamer is die „kerk". Maar dis ook goed genoeg. Die kerk is daar waar die Woord van God reg verkondig word en die sakramente bedien word volgens die instelling van Christus. Die predikante in wie se gemeentes ouetehuise resorteer, het hulle hande vol. Hulle het hulle kansels waar hulle soggens én saans moet staan. Hulle moet Sondae-middae of .sommer in die week" die Woord in daardie "kerk", die sitkamer van die ouetehuis bedien. Hulle moet ook sterk stemme hê om die bejaardes wat met die hand agter die oor luister, .,tegemoet" te kom. (Terwyl mens preek kán dit gebeur dat iemand wat nie goed hoor nie, uitroep: „harder asseblief!") Nou kan die predikant voltyds in hierdie "gemeente", 'n besondere "gemeente", voortgaan.

Uit hierdie reformatoriese bemoeienis vloei voort die gang van die kerk na die bejaarde toe. Dit is so omdat die ouetehuis tog nie kan leegloop op pad na die kerkgebou nie; so 'n beweeglikheid is vir baie min bejaardes beskore. Die oorgrote meerderheid van die inwoners is maar al te bly wanneer hulle Sondagmôre kan sê: "vandag het ons kerk." Indien die erediens in die tehuis om $3 \mathrm{~nm}$. begin, maak hulle kompleet soos in die ou dae toe die eerste en tweede "geluid" gelui het. Hulle stap al vroeg aan. Vir sommige is dit ' $n$ hele opoffering om in die sitkamer uit te kom. Hulle kom treetjie vir treetjie - sommige op hulle rystoele - ander word deur hulle maats gesteun. Hulle moet oppas om nie op mekaar se liddorings te trap nie. En as die dominee nou tien minute "voor die tyd" kan kom, geniet hulle dit om hulle „ou geliefde" psalms en gesange voor die erediens te sing. Hulle het groot geword in die dae toe ons volk nog van harte dikwels saamgesing het - stadig, op lang note, maar diep religieus, aangrypendl En as die erediens 
verby is? "Wee" die dominee wat dink dat hy hulle gaan ontglip om sy dorstige keel by die pastorie te gaan natmaak. Nee, nou begin die groetery. Hulle sê een en almal: "dankie dominee, dit was sielevoedsel". 'n Paar wat in hulle kamers siek lê, stuur boodskappe met hulle maats: „sê vir dominee ek lê, ek voel nie te lekker nie, miskien kan hy nog by my aankom!" Terwyl die preek aan die gang is, merk die dominee so hier en daar ' $n$ instemmende hoofknik asof hulle wil sê: „Dis nes u sê." Jammer net dat dominee nie meer 'n manelpak wil dra nie. Hy trek sommer so .,privaat" aan. „En hoekom het mevrou nie vandag saamgekom nie, dominee?" "Tannie sien, dis maar bietjie moeilik. Ons verwag mense. „Maar dominee moet die mense saambring. Sê baie groete vir mevrou."

Is dit nie ' $n$ deel van die pastoraat wat sprankelend afwissel met erns en humor nie? Woordverkondiging in die bejaardehuise, met die daarby behorende noodsaaklike pastoraat in al sy aspekte, is ' $n$ aangeleentheid wat van tyd tot tyd die aandag van ons Algemene Kerkvergadering moet geniet en deur die kerk altyd weer in oënskou geneem moet word. Profetiese en priesterlike werk vloei hiér op besondere wyse ineen!

6) Dr. Adolf Alwohn. Het Genezende Woord. G. F. Callenbach, N.V. Uitgever. Nykerk 1959.

7) Dr. A. Th. Stegenga. „Zielzorg aan hen die Bejaard zijn." Artikel in die bundel Praktisch Theologische Handboekjes. Boekencentrum, s'Gravenhage 1959.

8) Dr. P. Blaauw. „De Prediking tot Ouden van Dagen”, in „Handboek voor de Prediking". Üitg. mpy. Holland, Amsterdam 1948.

9) E. B. Hurlock. "Developmental Psychology." McGraw-Hill Book Company. Inc. New York, Toronto, London, 1959.

10) Dr. P. J. T. Koekemoer. Artikel in Hervormde Teologiese Studies. .Terreinverkenning insake die verhouding van Psigoterapie en Sielsorg." 20ste Jaargang, Afl. 2, Januarie 1965. N.H.W.-Pers, Krugersdorp.

11) Dr. P. J. T. Koekemoer. Reeks artikels in Die Hervormer, Mei 1975 tot Mei 1976 ,Ons 'Bejaardes. Ken ons hulle?" 